\title{
MEF2 transcription factors: developmental regulators and emerging cancer genes
}

\author{
Julia R. Pon ${ }^{1}$ and Marco A. Marra ${ }^{1,2}$ \\ ${ }^{1}$ Canada's Michael Smith Genome Sciences Centre, BC Cancer Agency, Vancouver, Canada \\ 2 Department of Medical Genetics, University of British Columbia, Vancouver, Canada \\ Correspondence to: Marco A. Marra, email: mmarra@bcgsc.ca \\ Keywords: MEF2, transcription factor, cancer, gene regulation, developmental biology \\ Received: August 21, $2015 \quad$ Accepted: October 14, $2015 \quad$ Published: October 25, 2015
}

This is an open-access article distributed under the terms of the Creative Commons Attribution License, which permits unrestricted use, distribution, and reproduction in any medium, provided the original author and source are credited.

\section{ABSTRACT}

The MEF2 transcription factors have roles in muscle, cardiac, skeletal, vascular, neural, blood and immune system cell development through their effects on cell differentiation, proliferation, apoptosis, migration, shape and metabolism. Altered MEF2 activity plays a role in human diseases and has recently been implicated in the development of several cancer types. In particular, MEF2B, the most divergent and least studied protein of the MEF2 family, has a role unique from its paralogs in non-Hodgkin lymphomas. The use of genome-scale technologies has enabled comprehensive MEF2 target gene sets to be identified, contributing to our understanding of MEF2 proteins as nodes in complex regulatory networks. This review surveys the molecular interactions of MEF2 proteins and their effects on cellular and organismal phenotypes. We include a discussion of the emerging roles of MEF2 proteins as oncogenes and tumor suppressors of cancer. Throughout this article we highlight similarities and differences between the MEF2 family proteins, including a focus on functions of MEF2B.

\section{INTRODUCTION}

The MEF2 transcription factors have a diversity of functions in a wide range of tissues and have been implicated in numerous diseases. Alterations affecting MEF2 proteins have long been known to contribute to development and neurological disorders but more recently have been implicated as drivers of cancer development. Moreover, the regulatory networks of MEF2 proteins are now being characterized in unprecedented detail. However, differences between the activities of MEF2 proteins are often not readily discernible in research reports. MEF2B, the most divergent of the MEF2 family, has received the least attention perhaps because of the difficulties of generating MEF2B specific reagents. However, MEF2B was the only MEF2 family member strongly implicated in lymphoma development, indicating that its distinct features are relevant to human disease.

Within the last ten years, functions of MEF2 proteins have been reviewed in particular cell types (e.g. neurons [1-3], muscle [4, 5] and hematopoietic cells [6]) or from the perspective of a particular discipline (e.g. developmental biology [7]). This review surveys findings from across tissue types and from molecular, cellular and organismal levels. We then discuss the roles of MEF2 protein in disease processes, with a focus on the latest implications of MEF2 proteins in cancer development. Throughout this discussion we highlight advances made using genome-scale technologies and distinguish activities of each of the MEF2 proteins. We attend in particular to how the functions of MEF2B compare with those of its paralogs. Overall, the activities of MEF2 proteins exemplify the context dependent and pleiotropic effects that transcription factors can have in normal and disease tissues.

\section{MEF2 FAMILY PROTEINS}

The myocyte enhancer factor 2 (MEF2) family of human transcription factors consists of four proteins, MEF2A, $-\mathrm{B},-\mathrm{C}$ and $-\mathrm{D}$, each of which has a homolog in other vertebrates [7]. $M E F 2 A$ and $-C$ have the most similar sequences, likely resulting from a duplication event that occurred near the origin of vertebrates [8]. In contrast, 
Table 1: Effects of MEF2 alterations in cancers.

\begin{tabular}{|c|c|c|c|c|c|}
\hline Cancer type & $\begin{array}{l}\text { MEF2 } \\
\text { protein } \\
\text { involved }\end{array}$ & $\begin{array}{l}\text { Role of } \\
\text { MEF2 } \\
\text { protein }\end{array}$ & $\begin{array}{l}\text { Alteration of MEF2 } \\
\text { protein }\end{array}$ & Effects of MEF2 alteration & References \\
\hline $\begin{array}{l}\text { Immature T-cell } \\
\text { acute lymphoblastic } \\
\text { leukemia }\end{array}$ & MEF2C & Oncogene & $\begin{array}{l}\text { Increased } \\
\text { expression due to } \\
\text { rearrangements or } \\
\text { alterations affecting } \\
\text { interacting proteins. }\end{array}$ & Inhibition of differentiation. & {$[124]$} \\
\hline $\begin{array}{l}\text { B-cell acute } \\
\text { lymphoblastic } \\
\text { leukemia }\end{array}$ & MEF2D & Oncogene & $\begin{array}{l}\text { Fusion with } \\
\text { DAZAPI. }\end{array}$ & $\begin{array}{l}\text { Promotion of colony formation } \\
\text { and proliferation in low serum } \\
\text { conditions. Inhibition of } \\
\text { apoptosis. }\end{array}$ & {$[125]$} \\
\hline Myeloid leukemia & MEF2C & Oncogene & $\begin{array}{l}\text { Expression activated } \\
\text { by retroviral } \\
\text { insertion in mouse } \\
\text { model. Increased } \\
\text { expression in patient } \\
\text { samples with } M L L \\
\text { rearrangements. }\end{array}$ & $\begin{array}{l}\text { Promotion of colony formation, } \\
\text { migration, invasion and stem- } \\
\text { cell-like properties. }\end{array}$ & {$[126-128]$} \\
\hline $\begin{array}{l}\text { Hepatocellular } \\
\text { carcinoma }\end{array}$ & $\begin{array}{l}\text { primarily } \\
\text { MEF2C } \\
\text { and } \\
\text { MEF2D }\end{array}$ & Oncogene & Increased expression. & $\begin{array}{l}\text { Epithelial-mesenchymal } \\
\text { transition and invasiveness. } \\
\text { Variable effects on proliferation. }\end{array}$ & {$[39,129,130,133]$} \\
\hline $\begin{array}{l}\text { Pancreatic ductal } \\
\text { adenocarcinoma }\end{array}$ & $\mathrm{MEF} 2 \mathrm{C}$ & Oncogene & $\begin{array}{l}\text { Increased expression } \\
\text { resulting from } \\
\text { decreased YY1 } \\
\text { expression. }\end{array}$ & $\begin{array}{l}\text { Promotion of } M M P 10 \\
\text { expression and invasiveness. }\end{array}$ & {$[136]$} \\
\hline $\begin{array}{l}\text { Lipo- and } \\
\text { leiomyosarcoma }\end{array}$ & $\begin{array}{l}\text { MEF2C, } \\
\text { MEF2D }\end{array}$ & $\begin{array}{l}\text { Tumor } \\
\text { suppressor }\end{array}$ & $\begin{array}{l}\text { Decreased MEF2 } \\
\text { activity and } \\
\text { abundance resulting } \\
\text { from increased } \\
\text { HDAC4 and PI3K/ } \\
\text { AKT activity. }\end{array}$ & $\begin{array}{l}\text { Promotion of cell proliferation } \\
\text { and anchorage independent } \\
\text { growth. }\end{array}$ & {$[141]$} \\
\hline Rhabdomyosarcoma & $\begin{array}{l}\text { MEF2C, } \\
\text { MEF2D }\end{array}$ & $\begin{array}{l}\text { Tumor } \\
\text { suppressor }\end{array}$ & $\begin{array}{l}\text { Loss of MEF2D } \\
\text { expression. } \\
\text { Increased ratio of } \\
\text { MEF2C } \alpha 1 \text { (less } \\
\text { active isoform) } \\
\text { compared to } \\
\text { MEF2C } \alpha 2 \text {. } \\
\end{array}$ & $\begin{array}{l}\text { Inhibition of differentiation. } \\
\text { Promotion of cell proliferation, } \\
\text { anchorage independent growth } \\
\text { and cell migration. }\end{array}$ & {$[113,142]$} \\
\hline $\begin{array}{l}\text { Diffuse large B-cell } \\
\text { lymphoma and } \\
\text { follicular lymphoma }\end{array}$ & $\begin{array}{l}\text { MEF2B, } \\
\text { very } \\
\text { rarely } \\
\text { MEF2C }\end{array}$ & $\begin{array}{l}\text { Tumor } \\
\text { suppressor }\end{array}$ & $\begin{array}{l}\text { Nonsynonymous } \\
\text { mutations in the } \\
\text { MADS and MEF2 } \\
\text { domains with } \\
\text { hotspots at K4, Y69 } \\
\text { and D83. Primarily } \\
\text { nonsense, frameshift } \\
\text { and stop codon read- } \\
\text { through mutations in } \\
\text { the transactivation } \\
\text { domains. }\end{array}$ & $\begin{array}{l}\text { May de-repress chemotaxis. } \\
\text { May promote } M Y C \text { and } T G F B 1 \\
\text { expression. }\end{array}$ & {$[55,70,143-146]$} \\
\hline $\begin{array}{l}\text { Mantle cell } \\
\text { lymphoma }\end{array}$ & MEF2B & Unknown & $\begin{array}{l}\text { Primarily K23R } \\
\text { mutations. }\end{array}$ & Unknown. & {$[147,148]$} \\
\hline
\end{tabular}


$M E F 2 B$ appears to be the first of the $M E F 2$ family to have diverged from a single ancestral $M E F 2$ gene [8]. The commonly used model organisms $S$. cerevisiae, $C$. elegans, and D. melanogaster contain only one MEF2 family gene [7].

All MEF2 proteins contain three domains: an $\mathrm{N}$-terminal DNA-binding MADS domain, a central MEF2 domain and a $\mathrm{C}$-terminal transactivation domain [7]. The MADS and MEF2 domains are well conserved across the MEF2 family, with $91 \%$ and $68 \%$ amino acid identity, respectively, between MEF2A and the most divergent MEF2 protein, MEF2B [7]. The transactivation domain is less well conserved, with only $6 \%$ amino acid identity between MEF2A and -B [7].

\section{ROLES OF MEF2 PROTEINS IN VERTEBRATE ORGANISMS}

MEF2 family proteins play central roles in the differentiation, morphogenesis, and maintenance of several vertebrate tissue types (Figure 1). The MEF2 proteins were named myocyte enhancer factors because of their roles in muscle cell differentiation [9]. MEF2A cooperates with other factors to promote skeletal muscle differentiation [10-12] and MEF2C promotes differentiation of mouse smooth muscle cells [13]. Interestingly, MEF2B mediates de-differentiation of vascular smooth muscle cells in response to cyclic stretch [14]. Multiple MEF2 proteins are likely involved in cardiac muscle differentiation, as competitive inhibition of binding to MEF2 sites impaired cardiac muscle differentiation [15] but knockouts of individual Mef2 genes did not [16-18]. Indeed, MEF2A, $\mathrm{B}$ and $-\mathrm{C}$ have all been implicated in cardiac muscle differentiation [19-23].

MEF2C is also required for normal neural differentiation. Mice with a Mef $2 c$ deletion in neural progenitor cells had less mature neurons, smaller brain sizes and severe behavioral abnormalities [24]. Conversely, expression of constitutively active MEF2C caused embryonic stem cells to differentiate into neurons [25]. Furthermore, MEF2 proteins have roles in hematopoetic cell differentiation. MEF2C promotes precursor cell commitment towards lymphoid rather than myeloid lineages and promotes development towards monocyte rather than granulocyte fates [6]. In B-cells, MEF2C activity is necessary for germinal centre formation [26, 27] and MEF2B and MEF2D are involved in maintaining Epstein-Barr virus latency [28, 29]. Interestingly, the Drosophila MEF2 protein coordinates immune functions with metabolic activities. Infection triggers the de-phosphorylation of MEF2 proteins in Drosophila fat pads, causing MEF2 proteins to switch from promoting the expression of enzymes involved in anabolic metabolism to instead promoting the expression of anti-microbial peptides [30]. Recruitment of MEF2 to anti-microbial peptide genes occurs through the association of the unphosphorylated form of MEF2 with TATA binding proteins. A role for human MEF2A and MEF2D in regulating expression of the glucose transporter gene GLUT4 has been confirmed [31] and glycogen was aberrantly accumulated in the muscle of Mef $2 c$ knockout mice [32].

Other activities of MEF2A, $-\mathrm{C}$ and $-\mathrm{D}$ relate to the regulation of cytoskeletal structures. For instance, deletion of $M e f 2 c$ in skeletal muscle cells resulted in sarcomere disorganization [33]. Neuronal cytoskeletal structures are regulated in part by MEF2A and MEF2D. Indeed, MEF2A and MEF2D constrain memory formation through their suppression of dendritic spine and excitatory synapse formation [34-36]. MEF2 proteins also contribute to the formation of large-scale tissue structures. For instance, Mef $2 c$ null mice have cardiac looping defects [16] and mice heterozygous for Mef $2 c$ deletion had decreased ossification and impaired chondrocyte hypertrophy in the sternum [18]. Neural crest-specific deletion of Mef2c produced defects in craniofacial morphogenesis [37]. The formation of craniofacial structures requires neural crest precursor cells to undergo epithelial-mesenchymal transition (EMT) and migrate to appropriate locations [38]. As MEF2A, -C and -D promoted EMT of hepatocellular carcinoma cells [39], they may also promote EMT of the neural crest cells.

Finally, MEF2A, -C and -D have roles in regulating apoptosis. MEF2C activity in endothelial cells [40] and MEF2A, -C and -D activity in developing neurons [41-43] inhibits apoptosis downstream of mitogenactivated protein kinase signaling. Interestingly, in mature neurons exposed to stress the anti-apoptotic effects of MEF2 proteins can be overcome by activation of caspase-mediated cleavage of the MEF2A, -C and -D transactivation domains $[43,44]$. Some of the remaining fragments contain dimerization domains that can inhibit the activity of intact MEF2 proteins in a dominant negative fashion [44]. In contrast, in T-cells MEF2C and MEF2D actively promote apoptosis downstream of T-cell receptor signaling by promoting the expression of Nur77 [45-47]. Although MEF2 proteins also promote Nur77 expression in neurons, functions of NUR77 in neurons relate to the inhibition of synaptic structure formation rather than the promotion of apoptosis [48, 49].

Knockout mouse models have also provided insight into the potential redundancy between MEF2 proteins. Mef2a [17] and Mef2c [50] null mice exhibited neonatal and embryonic lethality, respectively. Thus, MEF2A and MEF2C each perform some functions that cannot be adequately performed by other MEF2 proteins. Specifically, Mef2a null mice exhibited myocardial mitochondrial defects [17] whereas Mef2c null mice failed to undergo normal cardiac morphogenesis [50] and had severe vascular abnormalities[13]. In contrast, mice null for either Mef2b [16] or Mef2d [51] were viable and had no obvious abnormalities. Thus, either MEF2B and 
MEF2D do not contribute to development or other MEF2 proteins are able to compensate for the loss of MEF2B or MEF2D activity during development. However, adult $M e f 2 d$ knockout mice showed a reduced response to stress signals that would normally trigger cardiac hypertrophy and fibrosis [51], indicating MEF2D's activities are not entirely redundant.

Interestingly, the expression pattern of $M e f 2 b$ mRNA indicates that MEF2B, like its paralogs, may contribute to development and maintenance of a variety of tissue types. Similar to other Mef2 genes, Mef $2 b$ mRNA transcripts have been detected in developing cardiac muscle cells, skeletal muscle cells, neurons, neural crest cells, whisker follicle cells and chondrocytes of mouse embryos [52]. Rodent $M e f 2 b$ mRNA expression has also been reported in the proliferating smooth muscle cells of injured arteries [53] and in the brain's cortex, olfactory blub and amygdala [1]. Human $M E F 2 B$ mRNA expression has been detected in B-cell and T-cell lymphomas [54]. Further investigation indicated that $M E F 2 B$ mRNA is expressed in germinal centre (GC) B-cells but not in naïve $\mathrm{B}$-cells or in B-cells that have differentiated into plasma cells $[54,55]$. Of the mouse MEF2 genes, Mef2c has the most similar expression pattern to MEF2B and may thus have the most similar cellular functions [52]. However, the cell types containing appreciable levels of MEF2B protein may be a subset of those expressing $M E F 2 B$ mRNA, as the translation of other $M E F 2$ mRNAs is known to be suppressed in many tissue types [56]. MEF2B protein has been detected in GC B-cells, fibroblasts, myoblasts, myotubes and vascular smooth muscle cells $[52,53,55$, 57].

\section{GENOME-WIDE TARGET GENE IDENTIFICATION}

Attempts to better understand the role of MEF2 proteins have included attempts to identify MEF2 target genes throughout the genome. The target genes identified for different MEF2 proteins in different cell types tended to be enriched for different functional annotation groups. For instance, a study of MEF2A DNA-binding sites in cardiomyocytes reported that candidate direct target genes were enriched for functions related to heart and muscle development and cytoskeleton organization [20]. In contrast, a study of MEF2A and -D in hippocampal neurons identified target genes that tended to have functions at neural synapses and expression only in central nervous system cells [58]. Effects of a constitutively active MEF2 protein on global gene expression patterns in human neural progenitor cells were also recently assessed [59]. A study of the role of $\mathrm{MEF} 2 \mathrm{C}$ in bone formation found that genes associated with $\mathrm{MEF} 2 \mathrm{C}$ binding sites were enriched for genes that regulate bone turnover [60]. In HEK293 cells, MEF2B target genes were enriched for regulators of cell migration and genes involved in epithelial- mesenchymal transition. Target genes of MEF2B also included the cancer genes $M Y C, T G F B 1, C A R D 11, R H O B$ and NDRG1. Other ChIP-seq datasets available include those produced by the ENCODE consortium for MEF2A and MEF2C in GM12878 lymphoblastoid cells and for MEF2A in K562 myelogenous leukemia cells [61].

One study has directly compared target gene sets of each of the MEF2 proteins in mouse myoblasts [12]. In that study, genes whose expression levels were altered by reducing levels of a MEF2 protein were considered candidate target genes of that MEF2 protein. The numbers of candidate target genes ranged from 110 for MEF2D to 4,020 for MEF2A. Of the candidate target genes for one MEF2 protein, $10 \%$ to $81 \%$ were not candidate target genes of any other MEF2 protein. These differences between target gene sets are consistent with evidence that each MEF2 protein has some cellular functions distinct from those of the other MEF2 proteins. The 21 target genes shared by all four MEF2 proteins were enriched for regulation by calpain proteases, neural NOS signaling, integrin signaling, amyloid processing and FAK signaling pathways.

The notion that MEF2 proteins have target genes unique from those of their paralogs is also supported by earlier studies identifying differences between the target genes of MEF2B and those of other MEF2 proteins. MEF2B was the only MEF2 protein to bind a region required for maintaining $S M H C$ expression [62] and MEF2B overexpression but not MEF2D overexpression increased BZLF1 transcription [29]. Similarly, MEF2B overexpression but not MEF2A or -C overexpression increased SOST expression downstream of the ECR5 enhancer region [63]. Conversely, MEF2B may not regulate some genes that are direct targets of other MEF2 proteins: MEF2B was the only MEF2 protein that did not bind regulatory sequences near NUR77 [64] or the immunoglobulin J chain gene [65].

\section{FUNCTIONS OF THE MADS AND MEF2 DOMAINS IN MEF2 PROTEINS}

The MADS box is a region of 56 amino acids highly conserved across the MADS family proteins [66], whereas the MEF2 domain is a 29 amino acid region unique to MEF2 family proteins [67]. Both the MADS and MEF2 domains are required for DNA-binding [68]. Notably, MEF2 proteins bind DNA as dimers and the MADS and MEF2 domains are essential for dimerization [68]. Complexes thought to represent MEF2A-MEF2D heterodimers, MEF2C-MEF2D heterodimers and MEF2D homodimers have been identified in HEK293 cells [69]. Although the binding site motifs generated for MEF2A and $\mathrm{C}$ in lymphoblastoid cells [61] are nearly identical to that generated for MEF2B in HEK293A cells [70], DNA binding affinity may differ between MEF2 proteins. In particular, MEF2B is the only MEF2 protein to contain 
glutamine (Q) rather than glutamic acid (E) at residue 14 . Q14E mutation of MEF2B increased DNA binding by approximately two-fold [52], consistent with the notion that MEF2B may have slightly reduced affinity for DNA binding sites when compared to other MEF2 proteins.

Dissociation constants for DNA-binding have been determined for MEF2A [71] and MEF2C [72, 73]. However, these studies used MEF2 proteins expressed in bacteria, where the MEF2 proteins escaped post-translational modifications that modulate their DNA binding affinity. For instance, casein kinase II phosphorylates S59 of MEF2C, a modification that enhances MEF2C DNA binding by five-fold [74]. Similarly, acetylation of K4 increases MEF2C DNA binding [75]. S59 and K4 are conserved in MEF2A, -B and $-\mathrm{D}$, though their post-translational modification has only been investigated in MEF2C. Cell type specific factors may also influence DNA binding specificity. Indeed, in neuronal cells compared to muscle cells, MEF2A showed additional constraints for DNA-binding based on the sequences flanking MEF2 motifs [76].

The MEF2 domain is also involved in interactions with co-activators and co-repressors. Co-repressors that are thought to associate with the MEF2 domains of all MEF2 family proteins include the class IIa histone deacetylases HDAC4, -5, -7 and -9 [77-80]. Although class IIa HDACs have minimal deacetylase activity [81, 82], they can mediate transcriptional repression by recruiting other co-repressors such as HP-1, CtBP and class I HDACs [82-84]. Another co-repressor interacting directly with the MEF2 domain is CABIN1 [46, 85]. CABIN1 also interacts with class I HDACs [46] and can interact with the H3K9 methyltransferase SUV39H1 [86]. Co-activators binding the MEF2 domains of MEF2A [87], -C [88] and -D [46, 89] include the histone acetyltransferases CREBBP and p300, which are structural and functional homologs [90].

Given these interactions with histone modifying enzymes, MEF2 proteins may alter expression of their target genes by promoting changes in histone modification. Alternatively, HDACs and p300 may modulate MEF2 target gene expression by altering acetylation states of MEF2 proteins themselves. Deacetylation of MEF2D by HDAC4 allows MEF2D to be sumoylated [91]. Sumoylation inhibits the capacity of MEF2 proteins to activate transcription [91]. Conversely, p300 can acetylate MEF2C, promoting MEF2C's transcriptional activity [75, 92]. p300 may also play a structural role linking MEF2 proteins to other transcription factors and transcriptional machinery, as p300 can interact with basal transcription factors and RNA polymerase II [93].

Because their binding sites on MEF2 proteins overlap, CABIN1, class IIa HDACs, CREBBP and p300 may compete to bind MEF2 proteins [46]. Indeed, decreased interaction of CABIN1 with MEF2D correlated with an increase in the interaction of MEF2D with $\mathrm{p} 300$ [46]. Association of HDACs and CABIN1 with MEF2D is inhibited by increased intracellular calcium levels [46]. Specifically, high calcium levels promote nuclear export of CABIN1 and class II HDACs [94-96] and cause CABIN1 and class II HDACs to be sequestered into complexes with calcium-calmodulin [46]. Regulation of these and other co-repressors by calcium may explain why the expression of some MEF2 target genes is calcium sensitive (reviewed in McKinsey et al., 2002). For instance, Nur77 expression in T-cells is dependent on the presence of MEF2 binding sites and is induced by calcium signaling [97]. Similarly, treatment with a calcium ionophore increased MEF2dependent luciferase expression in T-cells [47].

MEF2-dependent gene expression may also be regulated by calcium signaling downstream of B-cell receptor (BCR) activation in B-cells. Consistent with this notion, most gene expression differences between mice with B-cell specific Mef2c deletions and control mice were evident only when BCR signaling was activated [27]. Specifically, activation of BCR signaling tended to increase MEF2C target gene expression in control B-cells but not in MEF2C deficient B-cells. However, BCR signaling involves multiple signal transduction pathways, including activation of $\mathrm{p} 38$ via protein kinase $\mathrm{C}$ (PKC) [98]. p38 can phosphorylate all MEF2 proteins, including MEF2B [69]. In muscle cells, phosphorylation by p38 promotes association of MEF2C and MEF2D with the histone methyltransferase KMT2D (also known as MLL2 and MLL4) [99]. p38 and calcium signaling may thus contribute synergistically to regulation of MEF2 target gene expression. This notion is supported by evidence that the treatment of cells with both the calcium ionophore ionomycin and the PKC activator PMA produced greater MEF2-dependent luciferase expression than treatment with either agent alone [47].

Other transcription factors can also cooperate with MEF2 proteins through interaction with the MADS or MEF2 domains. A well-studied example is the interaction of MEF2 proteins with Myogenic Regulatory Factors (MRFs). MEF2A, -C and -D only induced muscle gene expression in transfected fibroblasts when a MRF protein was co-expressed [11]. Once associated with MRFs, MEF2 proteins are thought to promote interactions between MEF2-MRF complexes and transcriptional machinery [100]. Interestingly, even though interaction with MRFs occurs through the MADS box of MEF2 proteins, MEF2 DNA-binding activity is not required for induction of a muscle gene expression program [11]. Similarly, the MADS and MEF2 domains of MEF2A, -C and -D can interact with GATA transcription factors to synergistically activate cardiac-specific gene expression, without requiring MEF2 DNA-binding capacity [101]. Thus, MEF2 proteins may affect expression of genes without MEF2 binding sites, through interactions with other transcription factors. 


\section{FUNCTIONS OF THE TRANSACTIVATION DOMAINS OF MEF2 PROTEINS}

The MADS and MEF2 domains of MEF2 proteins are sufficient to recruit certain coregulators (discussed above), but are not sufficient to strongly activate the expression of all target genes. For instance, MEF2B and MEF2C proteins containing the MADS and MEF2 domains but lacking most of their transactivation domain had eliminated and reduced capacities, respectively, to activate expression of a MEF2-dependent reporter gene $[52,68]$. Interestingly, when the MADS and MEF2 domains of MEF2C were replaced with a GAL4 DNA binding domain, the resulting fusion protein could activate the expression of a reporter gene whose promoter contained a GAL4 binding site [68]. Thus, the coregulators that interact with the MADS and MEF2 domains are not essential for MEF2C to activate the expression of some target genes. Rather, coregulators recruited by the MADS and MEF2 domains may modulate the degree of target gene activation.
The mechanisms by which MEF2 transactivation domains activate transcription remain unclear. One possible mechanism is through interaction with the positive transcription elongation factor $\mathrm{b}(\mathrm{P}-\mathrm{TEFb})$, which hyperphosphorylates the C-terminal region of RNA polymerase II to promote transcription [102]. P-TEFb was co-immunoprecipitated with MEF2A, -C and -D [103] and overexpression of $\mathrm{P}-\mathrm{TEFb}$ increased MEF2-dependent transcription. Furthermore, P-TEFb was recruited to MEF2 binding sites when MEF2-dependent transcription was activated. However, it remains unknown which domains of MEF2 proteins are required for interaction with P-TEFb.

An additional function of MEF2 transactivation domains is to integrate regulatory signals. Numerous sites of post-translational modification have been identified in the transactivation domains, including phosphorylation sites for p38 [69, 104] (discussed above), BMK1 [105] and PKA $[55,106]$. BMK1 phosphorylates and activates MEF2A, -C and -D but not MEF2B [105]. In contrast, both MEF2B and MEF2D are phosphorylated by PKA $[55,106]$. Phosphorylation at some sites in the MEF2B, -C

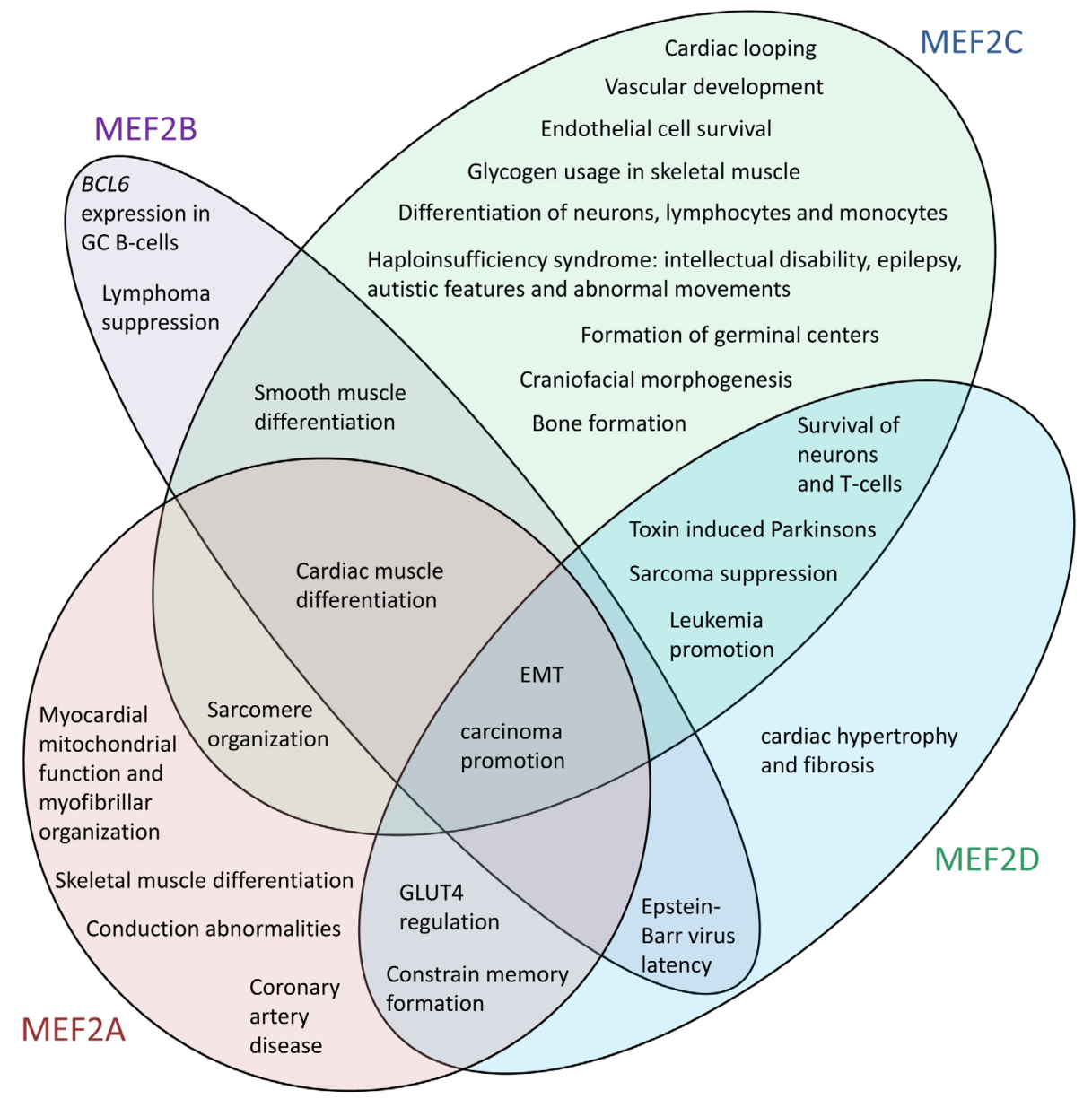

Figure 1: The human MEF2 proteins have distinct but overlapping sets of functions. References for noted functions are provided throughout the text. A function is noted for a MEF2 protein only where it has been demonstrated for that MEF2 protein. The lack of indication that a MEF2 protein is involved in a function may be because the capacity of that MEF2 protein to regulate that function has not yet been investigated. 
and -D transactivation domains promotes sumoylation at nearby residues. and decreases MEF2-dependent reporter gene expression $[55,107,108]$. However, only MEF $2 C$ contains a splice acceptor site that allows its sumoylation site to be spliced out. MEF2C isoforms lacking the sumoylation site thus escape repression [109]. MEF2 protein phosphorylation can also promote ubiquitination. Specifically, phosphorylation by CDK4/cyclin D1 at S98 and S110 allows MEF2D to interact with the E3 ligase SKP2, which mediates the ubiquitination and degradation of MEF2C and -D [110]. Degradation of MEF2C and -D via this mechanism de-represses progression into $\mathrm{S}$ phase [110].

Alternative splicing may also alter the transactivation domains of MEF2 proteins in other ways. For instance, MEF2A, -C and -D transcripts in striated muscle and neural tissue may include a $\beta$ exon that increases the capacity of the encoded protein to activate transcription [111]. However, the mechanism by which exon $\beta$ inclusion increases activity remains unclear. More clearly understood are the effects of the alternative third exons, $\alpha 1$ and $\alpha 2$, of MEF2A, $-\mathrm{C}$ and -D. These exons encode an amino acid sequence immediately $\mathrm{C}$-terminal to the MEF2 domain. MEF2C $\alpha 2$ is predominantly expressed in skeletal muscle [112] and promotes muscle-specific gene expression and myogenic differentiation to a greater extent than MEF2C $\alpha 1$, perhaps because of its decreased association with the corepressor HDAC5 [113].

In contrast to the many isoforms of MEF2A, $-\mathrm{C}$ and -D, only two isoforms of MEF2B have been reported: isoforms $\mathrm{A}$ and $\mathrm{B}$ [55]. Isoform $\mathrm{A}$ MEF2B includes all exons, whereas isoform $\mathrm{B}$ excludes exon 8 . The exclusion of exon 8 results in a frameshift that alters all amino acids C-terminal to those encoded by exon 7. Consequently, $40 \%$ of the amino acids in the transactivation domain of isoform $A$ are altered in isoform $B$, reducing the capacity of isoform B MEF2B to activate transcription [70].

\section{ROLES OF MEF2 FAMILY PROTEINS IN HUMAN DISEASE}

Of the MEF2 proteins, MEF2C has been associated with the widest range of disorders. For instance, increased MEF2C abundance has been associated with congenital heart defects [114] and decreased MEF2C abundance produces MEF2C haploinsufficiency syndrome. This syndrome is characterized by intellectual disability, epilepsy, autistic features and abnormal movements [115, 116]. Abnormal movement is also a characteristic of Parkinson's disease, the toxin-induced form of which has been associated with decreased MEF2C and -D activity $[117,118]$. Alterations affecting MEF2 target genes have been implicated in other neurological disorders including autism spectrum disorders [119], Alzheimer's disease [120] and Angelman syndrome [121]. Thus, alterations affecting MEF2 proteins may also impact these diseases.
In contrast to the neurological symptoms associated with decreased MEF2C and -D, decreased activity of MEF2A has been associated with an autosomal dominant form of coronary artery disease [122]. The only non-cancer disease or disorder in which MEF2B alterations may be implicated is intellectual disability, based on the weak evidence that $M E F 2 B$ was co-deleted with 10 or 75 other genes in two patients with intellectual disability [123].

\section{ONCOGENIC ACTIVITY OF MEF2 FAMILY GENES}

Roles of MEF2 proteins in cancer development have only recently been investigated (Table 1). MEF2 family genes are most well characterized as oncogenes of hematological cancers. For instance, increased $M E F 2 C$ expression is characteristic of immature T-cell acute lymphoblastic leukemia [124]. B-cell acute lymphoblastic leukemias also exhibit recurrent rearrangements producing DAZAP1/MEF2D fusion proteins that have oncogenic activity [125]. In mouse models of myeloid leukemia, Mef2c was able to act as a co-operating oncogene in combination with either Irf8 deficiency [126] or Sox4 activation [127], though it was insufficient to independently drive leukemia development. Myeloid leukemias initiated through MLL-AF9 displayed increased $M e f 2 c$ expression and required elevated MEF2C levels to maintain a high capacity for colony formation [128]. As $\mathrm{MEF} 2 \mathrm{C}$ is normally expressed in myeloid progenitor cells, it may be involved in conferring stem-cell like properties [6]. MEF2C also promoted the migration and invasion of leukemic cells [126]. In contrast to MEF2C and MEF2D, MEF2A and MEF2B have not been implicated in leukemia development.

Roles for MEF2 proteins in solid tumor development have also been proposed. MEF2A and -C mRNA and protein abundance tended to be greater in hepatocellular carcinoma (HCC) cells than normal liver cells [129] and MEF2D expression in HCC patient samples was associated with poor prognosis [130]. Providing further evidence that MEF2 activity may drive HCC development, 40 out of 193 HCC cases (21\%) had an amplification of a MEF2 gene [131, 132]. Although MEF2D was the most frequently amplified (29/193), all three other MEF2 family genes were amplified in at least one case.

MEF2A, -C and -D promoted HCC cell invasiveness by promoting epithelial-mesenchymal transition (EMT) [39]. Interestingly, TGF $\beta 1$ is both an upstream activator of MEF2 activity and is encoded by a MEF2 target gene [39]. Thus, a positive feedback loop may help maintain invasiveness. A separate study found that nuclear MEF2C promotes VEGF-mediated HCC cell invasion and angiogenesis, whereas cytoplasmic MEF2C sequesters $\beta$-catenin in the cytoplasm, reducing the capacity of $\beta$-catenin to promote cell proliferation [133]. Thus, MEF2C, like TGF $\beta$ cytokines [134], may act as a 
"double-edged sword" in HCC through its promotion of cell invasion and inhibition of cell proliferation [133]. Curiously, MEF2D had an effect on proliferation opposite that of MEF2C. MEF2D overexpression increased HCC cell proliferation and MEF2D-positive HCC cells had greater proliferation rates than MEF2D-negative HCC cells [130].

As some degree of EMT is necessary for the invasion and dissemination of carcinoma cells [135], MEF2 genes may also have oncogenic roles in the development of other types of carcinoma. Indeed, particularly poor prognosis in pancreatic ductal adenocarcinoma was associated with decreased expression of YY1, a suppressor of MEF2C expression [136]. Decreased YY1 expression increased the invasiveness of pancreatic adrenocarcinoma cells through MEF2C-mediated activation of MMP10 expression [136, 137]. Though not functionally characterized, roles for MEF2 proteins in other carcinomas may be predicted from the recurrence of alterations affecting $M E F 2$ genes. According to the cBioPortal database, 6 to $21 \%$ of ovarian

A

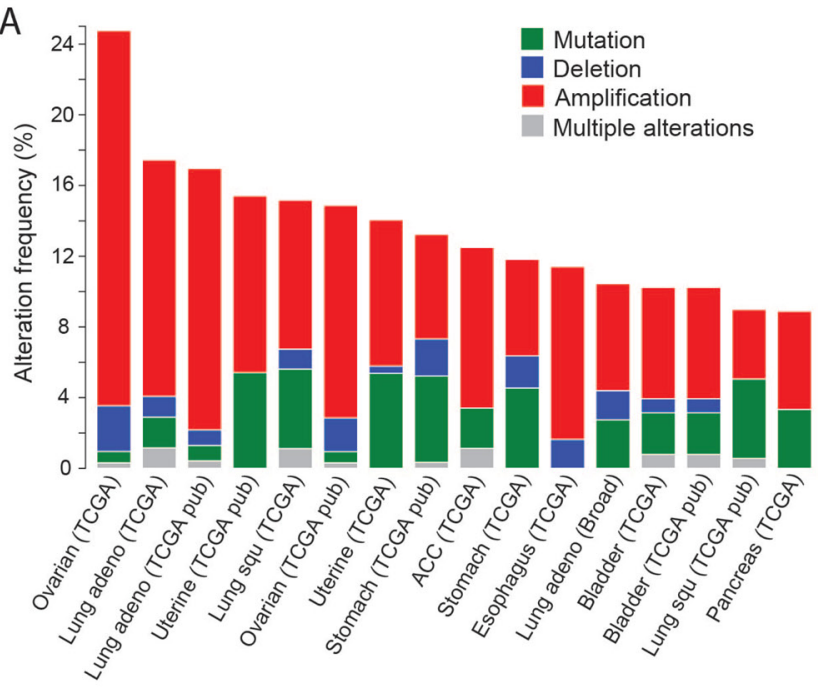

serous cystadenocarcinomas, lung squamous cell and adenocarcinomas, uterine endometriod carcinomas, stomach adenocarcinomas, adrenocortical carcinomas, esophageal carcinomas, bladder urothelial carcinomas and pancreatic adenocarcinomas contained an amplification of a $M E F 2$ gene, whereas instead of but 0 to $2.6 \%$ of these cancers contained a $M E F 2$ gene deletion [131, 132, 138-140] (Figure 2A). MEF2 genes thus may have the potential to act as oncogenes in these carcinomas. The cBioPortal data also illustrates how in some cancer types different MEF2 family genes have alterations at the different frequencies (Figure 2B) or tend to be affected by different types of alterations (Figure 2C). Even the most divergent family member, $M E F 2 B$, had amplifications in 3 to $9 \%$ of ovarian serous cystadenocarcinomas, adrenocortical carcinomas, and esophageal carcinomas $[131,132]$, indicating that it too may have oncogenic activity. Indeed, MEF2B promoted a mesenchymal gene expression signature and increased cell migration when overexpressed in HEK293 cells, consistent with the notion

B

Lung squamous cell carcinoma

MEF2A

MEF2B

MEF2C

MEF2D

genetic alteration
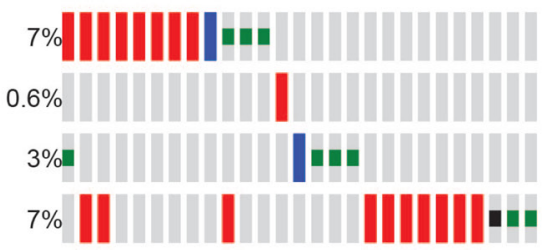

Amplification

Deep Deletion

Missense Mutation

Truncating Mutation

C

Ovarian serous cystadenocarcinoma

MEF2A

MEF2B

8\%

MEF2C

$9 \%$

|||||||||||||||||||||||||||

MEF2D

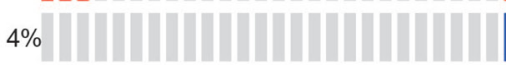

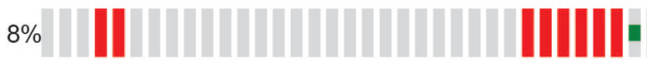

genetic alteration

Amplification

Deep Deletion

- Missense Mutation

Figure 2: MEF2 proteins may act as oncogenes in several types of carcinoma. A. Alterations affecting $M E F 2$ genes are present in up to $24 \%$ of samples of certain cancer types. Shown are data for cancer types in which $M E F 2$ genes were altered in over $8 \%$ of cases. In the shown cancer types, $M E F 2$ amplifications were more common than deletions, consistent with the notion that $M E F 2$ genes may act as oncogenes. B. Some $M E F 2$ genes are more frequently affected than others in certain cancer types. The plot shows how in lung squamous cell carcinoma alterations more commonly affect $M E F 2 A$ and $-D$ than $M E F 2 B$ and $-C$. C. In certain cancer types, some $M E F 2$ genes tend to be affected by different types of alterations than other $M E F 2$ genes. The plot shows how in ovarian serous cystadenocarcinoma the copy number alterations affecting $M E F 2 C$ are deletions, whereas those affecting other $M E F 2$ genes are amplifications. Data and plots were obtained using cBioportal [131, 132]. 
that it too promotes EMT [70].

\section{MEF2 FAMILY PROTEINS AS TUMOR SUPPRESSORS}

Tumor suppressor activities of MEF2 proteins have also been identified. For instance, MEF2 target gene expression tended to be decreased in lipo- and leiomyosarcomas compared to normal tissue [141]. This repression correlated with decreased MEF2C abundance and increased activity of negative regulators of MEF2 activity (i.e. HDAC4 and PI3K/AKT signaling). Inhibition of PI3K/AKT signaling and MEF2-HDAC interactions synergistically restored expression of MEF2 target genes and decreased leiomyosarcoma cell line proliferation. MEF2C and MEF2D may also act as tumor suppressors in rhabdomyosarcoma. In rhabdomyosarcoma cells compared to normal myoblasts, $M E F 2 D$ expression tended to be lost and a less active isoform of MEF2C tended to be expressed [113, 142]. The expression of exogenous $M E F 2 D$ in rhabdomyosarcoma cell lines promoted differentiation and inhibited cell proliferation, anchorage independent-growth and cell migration [142].

Roles of MEF2 proteins in non-Hodgkin lymphomas have also been identified. $M E F 2 B$ is the target of heterozygous somatic non-synonymous and indel mutations in 8 to $18 \%$ of diffuse large B-cell lymphoma (DLBCL) [143-146], 13\% of follicular lymphoma (FL) [143] and 3 to $7 \%$ of mantle cell lymphoma (MCL) $[147,148]$. Other MEF2 proteins were much less commonly affected in lymphoma [143, 144], indicating that MEF2B has a role unique from its paralogs in the B-cells from which these lymphomas arise. Mutations in the MADS and MEF2 domains represented $79 \%$ of $M E F 2 B$ mutations in DLBCL [143-146], $75 \%$ of $M E F 2 B$ mutations in FL [143] and $93 \%$ of $M E F 2 B$ mutations in MCL $[147,148]$. Mutation hotspots in DLBCL and FL were present at K4 (7\% of mutations), Y69 (8\% of mutations) and D83 (33\% of mutations) [143-146]. In contrast, $M E F 2 B$ mutations in MCL were predominantly K23R mutations (10 out of 14 mutations) [147, 148]. Why the mutation spectrum differs between MCL and other lymphomas remains to be determined. The recurrence of $M E F 2 B$ mutations at particular residues is consistent with the notion that $M E F 2 B$ mutations have either gain-offunction or dominant negative effects on MEF2B activity.

Although an early study found that some $M E F 2 B$ mutations increased the expression of a BCL6 reporter gene in HEK293 cells by disrupting interactions with the co-repressor CABIN1 [55], a subsequent study found that $M E F 2 B$ mutations tended to decrease endogenous MEF2B target gene activation in both HEK293 and DLBCL cells [70]. For the K4E and D83V mutations, decreased transcriptional activity resulted in part from decreased DNA binding. The notion that $M E F 2 B$ mutations decrease direct target gene activation is also consistent with the identification of two homozygous MEF2B deletions but no MEF2B amplifications in DLBCL [131, 132]. Moreover, the types of mutations common in the transactivation domain (i.e. nonsense, frameshift, stop codon read-through and splice site mutations) are typically inactivating [143]. Such inactivating mutations may not occur in the MADS and MEF2 domains as the capacity of the mutant proteins to dimerize must be preserved in order for them to have dominant negative effects. Although some nonsense mutations in the transactivation domain can remove sites for inhibitory post-translational modifications [55], they may also remove regions necessary for the transcriptional activation of key target genes. Indeed, deletion of the C-terminal third of the MEF2B transactivation domain decreased activation of a $M C K$ reporter gene in mouse embryonic fibroblasts [52]. Not only do some mutations disrupt over $90 \%$ of the transactivation domain [143], others result in constitutive production of protein almost identical to the less transcriptionally active isoform, isoform B [55].

Preliminary data indicates that loss of MEF2B activity de-represses DLBCL cell chemotaxis, indicating that the mutations may contribute to DLBCL and FL development by allowing migration outside of germinal centres [70]. MEF2B mutations also increased expression of the MYC oncogene and decreased expression of the TGFB1 tumor suppressor in HEK293 cells [70]. Such expression changes in DLBCL would be expected to promote lymphoma development [149-151].

\section{CONCLUSIONS}

Transcriptional regulation by MEF2 family members is modulated by a diversity of upstream regulators, splice isoforms, post-translational modifications, and coregulatory proteins. MEF2 proteins can thus perform diverse and cell-type-specific functions. Mapping MEF2 regulatory networks in the multitude of contexts in which they act is an ongoing endeavor. Differences in the roles of each MEF2 paralog highlight the importance of developing paralog-specific reagents and making the particular paralogs studied readily ascertainable in research reports.

Improving our understanding the pathways through which each MEF2 protein acts may prove relevant to diseases of cardiovascular, neural, musculoskeletal, blood and immune system cells. Indeed, the role of MEF2 proteins in common diseases such as autism spectrum disorders, Alzheimer's disease and numerous types of cancer remains to be fully elucidated. The involvement of MEF2 proteins in both cancers and developmental disorders underscores an emerging theme that cancer genes tend to have roles in development. Communication and collaboration between biochemists, cancer biologists, geneticists and developmental biologists will thus be essential for developing of a complete picture of the roles 
of $M E F 2$ genes and other cancer genes.

\section{ACKNOWLEDGMENTS}

The authors thank John Auston and family for their generous support. J.R.P. is supported by a CIHR Vanier Canada Graduate Scholarship, a Scriver MD/PhD Scholarship and a University of British Columbia Four Year Fellowship. M.A.M. is the University of British Columbia Canada Research Chair in Genome Science.

\section{GRANT SUPPORT}

This work was supported by the BC Cancer Foundation (NSA10108); the Terry Fox Research Institute (award \#1023); Genome Canada (award \#4108); Genome British Columbia and the Leukemia and Lymphoma Society of Canada.

\section{CONFLICTS OF INTEREST}

The authors declare that they have no competing interests.

\section{REFERENCES}

1. Rashid AJ, Cole CJ, Josselyn SA. Emerging roles for MEF2 transcription factors in memory. Genes, Brain, and Behavior. 2014; 13:118-25.

2. Dietrich J-B. The MEF2 family and the brain: from molecules to memory. Cell and Tissue Research. 2013; 352:179-90.

3. Yang Q, Mao Z. Dysregulation of autophagy and Parkinson's disease: the MEF2D link. Apoptosis: An International Journal on Programmed Cell Death. 2010; 15:1410-4.

4. Aziz A, Liu Q-C, Dilworth FJ. Regulating a master regulator: establishing tissue-specific gene expression in skeletal muscle. Epigenetics. 2010; 5:691-5.

5. McGee SL. Exercise and MEF2-HDAC interactions. Applied Physiology, Nutrition, and Metabolism = Physiologie Appliquée, Nutrition Et Métabolisme. 2007; 32:852-6.

6. Canté-Barrett K, Pieters R, Meijerink JPP. Myocyte enhancer factor $2 \mathrm{C}$ in hematopoiesis and leukemia. Oncogene. 2014; 33:403-10.

7. Potthoff MJ, Olson EN. MEF2: a central regulator of diverse developmental programs. Development (Cambridge, England). 2007; 134:4131-40.

8. Wu W, de Folter S, Shen X, Zhang W, Tao S. Vertebrate paralogous MEF2 genes: origin, conservation, and evolution. PloS One. 2011; 6:e17334.

9. Gossett LA, Kelvin DJ, Sternberg EA, Olson EN. A new myocyte-specific enhancer-binding factor that recognizes a conserved element associated with multiple muscle-specific genes. Molecular and Cellular Biology. 1989; 9:5022-33.

10. Wang DZ, Valdez MR, McAnally J, Richardson J, Olson $\mathrm{EN}$. The Mef2c gene is a direct transcriptional target of myogenic bHLH and MEF2 proteins during skeletal muscle development. Development (Cambridge, England). 2001; 128:4623-33.

11. Molkentin JD, Black BL, Martin JF, Olson EN. Cooperative activation of muscle gene expression by MEF2 and myogenic bHLH proteins. Cell. 1995; 83:1125-36.

12. Estrella NL, Desjardins CA, Nocco SE, Clark AL, Maksimenko Y, Naya FJ. MEF2 transcription factors regulate distinct gene programs in mammalian skeletal muscle differentiation. The Journal of Biological Chemistry. 2015; 290:1256-68.

13. Lin $\mathrm{Q}$, Lu J, Yanagisawa $\mathrm{H}$, Webb R, Lyons GE, Richardson JA, Olson EN. Requirement of the MADSbox transcription factor MEF2C for vascular development. Development (Cambridge, England). 1998; 125:4565-74.

14. Rodríguez AI, Csányi G, Ranayhossaini DJ, Feck DM, Blose KJ, Assatourian L, Vorp DA, Pagano PJ. MEF2B-Nox1 signaling is critical for stretch-induced phenotypic modulation of vascular smooth muscle cells. Arteriosclerosis, Thrombosis, and Vascular Biology. 2015; $35: 430-8$.

15. Karamboulas C, Dakubo GD, Liu J, De Repentigny Y, Yutzey K, Wallace VA, Kothary R, Skerjanc IS. Disruption of MEF2 activity in cardiomyoblasts inhibits cardiomyogenesis. Journal of Cell Science. 2006; 119:431521.

16. Lin Q, Schwarz J, Bucana C, Olson EN. Control of mouse cardiac morphogenesis and myogenesis by transcription factor MEF2C. Science (New York, NY). 1997; 276:14047.

17. Naya FJ, Black BL, Wu H, Bassel-Duby R, Richardson JA, Hill JA, Olson EN. Mitochondrial deficiency and cardiac sudden death in mice lacking the MEF2A transcription factor. Nature Medicine. 2002; 8:1303-9.

18. Arnold MA, Kim Y, Czubryt MP, Phan D, McAnally J, Qi X, Shelton JM, Richardson JA, Bassel-Duby R, Olson EN. MEF2C transcription factor controls chondrocyte hypertrophy and bone development. Developmental Cell. 2007; 12:377-89.

19. Hernández-Torres F, Martínez-Fernández S, Zuluaga S, Nebreda A, Porras A, Aránega AE, Navarro F. A role for p38alpha mitogen-activated protein kinase in embryonic cardiac differentiation. FEBS letters. 2008; 582:1025-31.

20. Schlesinger J, Schueler M, Grunert M, Fischer JJ, Zhang Q, Krueger T, Lange M, Tönjes M, Dunkel I, Sperling SR. The cardiac transcription network modulated by Gata4, Mef2a, Nkx2.5, Srf, histone modifications, and microRNAs. PLoS Genetics. 2011; 7:e1001313.

21. He A, Kong SW, Ma Q, Pu WT. Co-occupancy by multiple cardiac transcription factors identifies transcriptional 
enhancers active in heart. Proceedings of the National Academy of Sciences of the United States of America. 2011; 108:5632-7.

22. Wang Y-X, Qian L-X, Yu Z, Jiang Q, Dong Y-X, Liu X-F, Yang X-Y, Zhong TP, Song H-Y. Requirements of myocyte-specific enhancer factor $2 \mathrm{~A}$ in zebrafish cardiac contractility. FEBS letters. 2005; 579:4843-50.

23. Voronova A, Madhoun A Al, Fischer A, Shelton M, Karamboulas C, Skerjanc IS. Gli2 and MEF2C activate each other's expression and function synergistically during cardiomyogenesis in vitro. Nucleic Acids Research. 2012; 40:3329-47.

24. Li H, Radford JC, Ragusa MJ, Shea KL, McKercher SR, Zaremba JD, Soussou W, Nie Z, Kang Y-J, Nakanishi N, Okamoto S, Roberts AJ, Schwarz JJ, et al. Transcription factor MEF2C influences neural stem/progenitor cell differentiation and maturation in vivo. Proceedings of the National Academy of Sciences of the United States of America. 2008; 105:9397-402.

25. Li Z, McKercher SR, Cui J, Nie Z, Soussou W, Roberts AJ, Sallmen T, Lipton JH, Talantova M, Okamoto S, Lipton SA. Myocyte enhancer factor $2 \mathrm{C}$ as a neurogenic and antiapoptotic transcription factor in murine embryonic stem cells. The Journal of Neuroscience. 2008; 28:6557-68.

26. Khiem D, Cyster JG, Schwarz JJ, Black BL. A p38 MAPKMEF2C pathway regulates B-cell proliferation. Proceedings of the National Academy of Sciences of the United States of America. 2008; 105:17067-72.

27. Wilker PR, Kohyama M, Sandau MM, Albring JC, Nakagawa O, Schwarz JJ, Murphy KM. Transcription factor Mef2c is required for B cell proliferation and survival after antigen receptor stimulation. Nature Immunology. 2008; 9:603-12.

28. Gruffat H, Manet E, Sergeant A. MEF2-mediated recruitment of class II HDAC at the EBV immediate early gene BZLF1 links latency and chromatin remodeling. EMBO reports. 2002; 3:141-6.

29. Murata T, Narita Y, Sugimoto A, Kawashima D, Kanda T, Tsurumi T. Contribution of myocyte enhancer factor 2 family transcription factors to BZLF1 expression in Epstein-Barr virus reactivation from latency. Journal of virology. 2013; 87:10148-62.

30. Clark RI, Tan SWS, Péan CB, Roostalu U, Vivancos V, Bronda K, Pilátová M, Fu J, Walker DW, Berdeaux R, Geissmann F, Dionne MS. MEF2 is an in vivo immunemetabolic switch. Cell. 2013; 155:435-47.

31. Knight JB, Eyster CA, Griesel BA, Olson AL. Regulation of the human GLUT4 gene promoter: interaction between a transcriptional activator and myocyte enhancer factor 2A. Proceedings of the National Academy of Sciences of the United States of America. 2003; 100:14725-30.

32. Anderson $\mathrm{CM}, \mathrm{Hu} \mathrm{J}$, Barnes RM, Heidt AB, Cornelissen $\mathrm{I}$, Black BL. Myocyte enhancer factor 2C function in skeletal muscle is required for normal growth and glucose metabolism in mice. Skeletal Muscle. 2015; 5:7.

33. Potthoff MJ, Arnold MA, McAnally J, Richardson JA, Bassel-Duby R, Olson EN. Regulation of skeletal muscle sarcomere integrity and postnatal muscle function by Mef2c. Molecular and Cellular Biology. 2007; 27:8143-51.

34. Flavell SW, Cowan CW, Kim T-K, Greer PL, Lin Y, Paradis S, Griffith EC, Hu LS, Chen C, Greenberg ME. Activity-dependent regulation of $\mathrm{MEF} 2$ transcription factors suppresses excitatory synapse number. Science (New York, NY). 2006; 311:1008-12.

35. Pulipparacharuvil S, Renthal W, Hale CF, Taniguchi M, Xiao G, Kumar A, Russo SJ, Sikder D, Dewey CM, Davis MM, Greengard P, Nairn AC, Nestler EJ, et al. Cocaine regulates MEF2 to control synaptic and behavioral plasticity. Neuron. 2008; 59:621-33.

36. Cole CJ, Mercaldo V, Restivo L, Yiu AP, Sekeres MJ, Han J-H, Vetere G, Pekar T, Ross PJ, Neve RL, Frankland $\mathrm{PW}$, Josselyn SA. MEF2 negatively regulates learninginduced structural plasticity and memory formation. Nature Neuroscience. 2012; 15:1255-64.

37. Verzi MP, Agarwal P, Brown C, McCulley DJ, Schwarz JJ, Black BL. The transcription factor MEF2C is required for craniofacial development. Developmental Cell. 2007; 12:645-52.

38. Knecht AK, Bronner-Fraser M. Induction of the neural crest: a multigene process. Nature Reviews Genetics. 2002; 3:453-61.

39. Yu W, Huang C, Wang Q, Huang T, Ding Y, Ma C, Ma H, Chen W. MEF2 transcription factors promotes EMT and invasiveness of hepatocellular carcinoma through TGF- $\beta 1$ autoregulation circuitry. Tumour Biology: The Journal of the International Society for Oncodevelopmental Biology and Medicine. 2014; 35:10943-51.

40. Hayashi M, Kim S-W, Imanaka-Yoshida K, Yoshida T, Abel ED, Eliceiri B, Yang Y, Ulevitch RJ, Lee J-D. Targeted deletion of BMK1/ERK5 in adult mice perturbs vascular integrity and leads to endothelial failure. The Journal of Clinical Investigation. 2004; 113:1138-48.

41. Mao Z, Bonni A, Xia F, Nadal-Vicens M, Greenberg ME. Neuronal activity-dependent cell survival mediated by transcription factor MEF2. Science (New York, NY). 1999; 286:785-90.

42. Okamoto S, Krainc D, Sherman K, Lipton SA. Antiapoptotic role of the p38 mitogen-activated protein kinase-myocyte enhancer factor 2 transcription factor pathway during neuronal differentiation. Proceedings of the National Academy of Sciences of the United States of America. 2000; 97:7561-6.

43. Li M, Linseman DA, Allen MP, Meintzer MK, Wang X, Laessig T, Wierman ME, Heidenreich KA. Myocyte enhancer factor 2A and 2D undergo phosphorylation and caspase-mediated degradation during apoptosis of rat cerebellar granule neurons. The Journal of Neuroscience. $2001 ; 21: 6544-52$. 
44. Okamoto S, Li Z, Ju C, Scholzke MN, Mathews E, Cui J, Salvesen GS, Bossy-Wetzel E, Lipton SA. Dominantinterfering forms of MEF2 generated by caspase cleavage contribute to NMDA-induced neuronal apoptosis. Proceedings of the National Academy of Sciences of the United States of America. 2002; 99:3974-9.

45. Dequiedt F, Kasler H, Fischle W, Kiermer V, Weinstein M, Herndier BG, Verdin E. HDAC7, a thymus-specific class II histone deacetylase, regulates Nur77 transcription and TCR-mediated apoptosis. Immunity. 2003; 18:687-98.

46. Youn HD, Liu JO. Cabin1 represses MEF2-dependent Nur77 expression and $\mathrm{T}$ cell apoptosis by controlling association of histone deacetylases and acetylases with MEF2. Immunity. 2000; 13:85-94.

47. Youn HD, Sun L, Prywes R, Liu JO. Apoptosis of T cells mediated by $\mathrm{Ca} 2+$-induced release of the transcription factor MEF2. Science (New York, NY). 1999; 286:790-3.

48. Tian X, Kai L, Hockberger PE, Wokosin DL, Surmeier DJ. MEF-2 regulates activity-dependent spine loss in striatopallidal medium spiny neurons. Molecular and Cellular Neurosciences. 2010; 44:94-108.

49. Shalizi A, Gaudillière B, Yuan Z, Stegmüller J, Shirogane T, Ge Q, Tan Y, Schulman B, Harper JW, Bonni A. A calcium-regulated MEF2 sumoylation switch controls postsynaptic differentiation. Science (New York, NY). 2006; 311:1012-7.

50. Lin Q, Schwarz J, Bucana C, Olson EN. Control of mouse cardiac morphogenesis and myogenesis by transcription factor MEF2C. Science (New York, NY). 1997; 276:14047.

51. Kim Y, Phan D, van Rooij E, Wang D-Z, McAnally J, Qi X, Richardson JA, Hill JA, Bassel-Duby R, Olson EN. The MEF2D transcription factor mediates stress-dependent cardiac remodeling in mice. The Journal of Clinical Investigation. 2008; 118:124-32.

52. Molkentin JD, Firulli AB, Black BL, Martin JF, Hustad CM, Copeland N, Jenkins N, Lyons G, Olson EN. MEF2B is a potent transactivator expressed in early myogenic lineages. Molecular and Cellular Biology. 1996; 16:381424.

53. Firulli AB, Miano JM, Bi W, Johnson AD, Casscells W, Olson EN, Schwarz JJ. Myocyte enhancer binding factor-2 expression and activity in vascular smooth muscle cells. Association with the activated phenotype. Circulation Research. 1996; 78:196-204.

54. Swanson BJ, Jäck HM, Lyons GE. Characterization of myocyte enhancer factor 2 (MEF2) expression in $\mathrm{B}$ and $\mathrm{T}$ cells: MEF2C is a B cell-restricted transcription factor in lymphocytes. Molecular Immunology. 1998; 35:445-58.

55. Ying CY, Dominguez-Sola D, Fabi M, Lorenz IC, Hussein S, Bansal M, Califano A, Pasqualucci L, Basso K, DallaFavera R. MEF2B mutations lead to deregulated expression of the oncogene BCL6 in diffuse large B cell lymphoma. Nature immunology. 2013; 14:1084-92.
56. Black BL, Lu J, Olson EN. The MEF2A 3' untranslated region functions as a cis-acting translational repressor. Molecular and Cellular Biology. 1997; 17:2756-63.

57. Krenács D, Borbényi Z, Bedekovics J, Méhes G, Bagdi E, Krenács L. Pattern of MEF2B expression in lymphoid tissues and in malignant lymphomas. Virchows Archiv: An International Journal of Pathology. 2015; 467:345-55.

58. Flavell SW, Kim T-K, Gray JM, Harmin DA, Hemberg M, Hong EJ, Markenscoff-Papadimitriou E, Bear DM, Greenberg ME. Genome-wide analysis of MEF2 transcriptional program reveals synaptic target genes and neuronal activity-dependent polyadenylation site selection. Neuron. 2008; 60:1022-38.

59. Chan SF, Huang X, McKercher SR, Zaidi R, Okamoto S-I, Nakanishi N, Lipton SA. Transcriptional profiling of MEF2-regulated genes in human neural progenitor cells derived from embryonic stem cells. Genomics Data. 2015; $3: 24-7$.

60. Johnson ME, Deliard S, Zhu F, Xia Q, Wells AD, Hankenson KD, Grant SFA. A ChIP-seq-defined genomewide map of MEF2C binding reveals inflammatory pathways associated with its role in bone density determination. Calcified Tissue International. 2014; 94:396402.

61. Wang J, Zhuang J, Iyer S, Lin X, Whitfield TW, Greven MC, Pierce BG, Dong X, Kundaje A, Cheng Y, Rando OJ, Birney E, Myers RM, et al. Sequence features and chromatin structure around the genomic regions bound by 119 human transcription factors. Genome Research. 2012; 22:1798-812.

62. Katoh Y, Molkentin JD, Dave V, Olson EN, Periasamy M. MEF2B is a component of a smooth muscle-specific complex that binds an A/T-rich element important for smooth muscle myosin heavy chain gene expression. The Journal of biological chemistry. 1998; 273:1511-8.

63. Yu L, van der Valk M, Cao J, Han C-YE, Juan T, Bass MB, Deshpande C, Damore MA, Stanton R, Babij P. Sclerostin expression is induced by BMPs in human Saos-2 osteosarcoma cells but not via direct effects on the sclerostin gene promoter or ECR5 element. Bone. 2011; 49:1131-40.

64. Blaeser F, Ho N, Prywes R, Chatila TA. Ca(2+)-dependent gene expression mediated by MEF2 transcription factors. The Journal of Biological Chemistry. 2000; 275:197-209.

65. Rao S, Karray S, Gackstetter ER, Koshland ME. Myocyte enhancer factor-related B-MEF2 is developmentally expressed in B cells and regulates the immunoglobulin $\mathrm{J}$ chain promoter. The Journal of Biological Chemistry. 1998; 273:26123-9.

66. Shore P, Sharrocks AD. The MADS-box family of transcription factors. European journal of biochemistry / FEBS. 1995; 229:1-13.

67. Olson EN, Perry M, Schulz RA. Regulation of muscle differentiation by the MEF2 family of MADS box 
transcription factors. Developmental Biology. 1995; 172:214.

68. Molkentin JD, Black BL, Martin JF, Olson EN. Mutational analysis of the DNA binding, dimerization, and transcriptional activation domains of MEF2C. Molecular and Cellular Biology. 1996; 16:2627-36.

69. Zhao M, New L, Kravchenko VV, Kato Y, Gram H, di Padova F, Olson EN, Ulevitch RJ, Han J. Regulation of the MEF2 family of transcription factors by $\mathrm{p} 38$. Molecular and cellular biology. 1999; 19:21-30.

70. Pon JR, Wong J, Saberi S, Alder O, Moksa M, Grace Cheng S-W, Morin GB, Hoodless PA, Hirst M, Marra MA. MEF2B mutations in non-Hodgkin lymphoma dysregulate cell migration by decreasing MEF2B target gene activation. Nature Communications. 2015; 6:7953.

71. Octobre G, Lemercier C, Khochbin S, Robert-Nicoud M, Souchier C. Monitoring the interaction between DNA and a transcription factor (MEF2A) using fluorescence correlation spectroscopy. Comptes Rendus Biologies. 2005; 328:103340.

72. Meierhans D, Allemann RK. The N-terminal methionine is a major determinant of the DNA binding specificity of MEF-2C. The Journal of Biological Chemistry. 1998; 273:26052-60.

73. Meierhans D, Sieber M, Allemann RK. High affinity binding of MEF-2C correlates with DNA bending. Nucleic Acids Research. 1997; 25:4537-44.

74. Molkentin JD, Li L, Olson EN. Phosphorylation of the MADS-Box transcription factor MEF2C enhances its DNA binding activity. The Journal of Biological Chemistry. 1996; 271:17199-204.

75. Angelelli C, Magli A, Ferrari D, Ganassi M, Matafora V, Parise F, Razzini G, Bachi A, Ferrari S, Molinari S. Differentiation-dependent lysine 4 acetylation enhances MEF2C binding to DNA in skeletal muscle cells. Nucleic Acids Research. 2008; 36:915-28.

76. Andrés V, Cervera M, Mahdavi V. Determination of the consensus binding site for MEF2 expressed in muscle and brain reveals tissue-specific sequence constraints. The Journal of Biological Chemistry. 1995; 270:23246-9.

77. Han A, He J, Wu Y, Liu JO, Chen L. Mechanism of recruitment of class II histone deacetylases by myocyte enhancer factor-2. Journal of Molecular Biology. 2005; 345:91-102.

78. Miska EA, Karlsson C, Langley E, Nielsen SJ, Pines J, Kouzarides T. HDAC4 deacetylase associates with and represses the MEF2 transcription factor. The EMBO journal. 1999; 18:5099-107.

79. Lu J, McKinsey TA, Zhang CL, Olson EN. Regulation of skeletal myogenesis by association of the MEF2 transcription factor with class II histone deacetylases. Molecular Cell. 2000; 6:233-44.

80. Youn HD, Grozinger CM, Liu JO. Calcium regulates transcriptional repression of myocyte enhancer factor 2 by histone deacetylase 4 . The Journal of Biological Chemistry. 2000; 275:22563-7.

81. Lahm A, Paolini C, Pallaoro M, Nardi MC, Jones P, Neddermann P, Sambucini S, Bottomley MJ, Surdo P Lo, Carfí A, Koch U, De Francesco R, Steinkühler C, et al. Unraveling the hidden catalytic activity of vertebrate class IIa histone deacetylases. Proceedings of the National Academy of Sciences of the United States of America. 2007; 104:17335-40.

82. Fischle W, Dequiedt F, Hendzel MJ, Guenther MG, Lazar MA, Voelter W, Verdin E. Enzymatic activity associated with class II HDACs is dependent on a multiprotein complex containing HDAC3 and SMRT/N-CoR. Molecular Cell. 2002; 9:45-57.

83. Zhang CL, McKinsey TA, Olson EN. Association of class II histone deacetylases with heterochromatin protein 1: potential role for histone methylation in control of muscle differentiation. Molecular and Cellular Biology. 2002; 22:7302-12.

84. Zhang CL, McKinsey TA, Lu JR, Olson EN. Association of $\mathrm{COOH}$-terminal-binding protein (CtBP) and MEF2interacting transcription repressor (MITR) contributes to transcriptional repression of the MEF2 transcription factor. The Journal of Biological Chemistry. 2001; 276:35-9.

85. Han A, Pan F, Stroud JC, Youn H-D, Liu JO, Chen L. Sequence-specific recruitment of transcriptional corepressor Cabin1 by myocyte enhancer factor-2. Nature. 2003; 422:730-4.

86. Jang H, Choi D-E, Kim H, Cho E-J, Youn H-D. Cabin1 represses MEF2 transcriptional activity by association with a methyltransferase, SUV39H1. The Journal of Biological Chemistry. 2007; 282:11172-9.

87. He J, Ye J, Cai Y, Riquelme C, Liu JO, Liu X, Han A, Chen L. Structure of $\mathrm{p} 300$ bound to MEF2 on DNA reveals a mechanism of enhanceosome assembly. Nucleic Acids Research. 2011; 39:4464-74.

88. Sartorelli V, Huang J, Hamamori Y, Kedes L. Molecular mechanisms of myogenic coactivation by p300: direct interaction with the activation domain of $\mathrm{MyoD}$ and with the MADS box of MEF2C. Molecular and Cellular Biology. 1997; 17:1010-26.

89. Slepak TI, Webster KA, Zang J, Prentice H, O’Dowd A, Hicks MN, Bishopric NH. Control of cardiac-specific transcription by $\mathrm{p} 300$ through myocyte enhancer factor-2D. The Journal of Biological Chemistry. 2001; 276:7575-85.

90. Lundblad JR, Kwok RP, Laurance ME, Harter ML, Goodman RH. Adenoviral E1A-associated protein p300 as a functional homologue of the transcriptional co-activator CBP. Nature. 1995; 374:85-8.

91. Zhao X, Sternsdorf T, Bolger TA, Evans RM, Yao T-P. Regulation of MEF2 by histone deacetylase 4- and SIRT1 deacetylase-mediated lysine modifications. Molecular and Cellular Biology. 2005; 25:8456-64.

92. Ma K, Chan JKL, Zhu G, Wu Z. Myocyte enhancer factor 
2 acetylation by p300 enhances its DNA binding activity, transcriptional activity, and myogenic differentiation. Molecular and Cellular Biology. 2005; 25:3575-82.

93. Cohen I, Poręba E, Kamieniarz K, Schneider R. Histone modifiers in cancer: friends or foes? Genes \& Cancer. 2011; 2:631-47.

94. McKinsey TA, Zhang CL, Olson EN. Activation of the myocyte enhancer factor-2 transcription factor by calcium/ calmodulin-dependent protein kinase-stimulated binding of 14-3-3 to histone deacetylase 5. Proceedings of the National Academy of Sciences of the United States of America. 2000; 97:14400-5.

95. Pan F, Means AR, Liu JO. Calmodulin-dependent protein kinase IV regulates nuclear export of Cabin1 during T-cell activation. The EMBO Journal. 2005; 24:2104-13.

96. Lu J, McKinsey TA, Nicol RL, Olson EN. Signal-dependent activation of the MEF2 transcription factor by dissociation from histone deacetylases. Proceedings of the National Academy of Sciences of the United States of America. 2000; 97:4070-5.

97. Woronicz JD, Lina A, Calnan BJ, Szychowski S, Cheng L, Winoto A. Regulation of the Nur77 orphan steroid receptor in activation-induced apoptosis. Molecular and Cellular Biology. 1995; 15:6364-76.

98. Avalos AM, Meyer-Wentrup F, Ploegh HL. B-cell receptor signaling in lymphoid malignancies and autoimmunity. Advances in Immunology. 2014; 123:1-49.

99. Rampalli S, Li L, Mak E, Ge K, Brand M, Tapscott SJ, Dilworth FJ. p38 MAPK signaling regulates recruitment of Ash2L-containing methyltransferase complexes to specific genes during differentiation. Nature Structural \& Molecular Biology. 2007; 14:1150-6.

100. Black BL, Olson EN. Transcriptional control of muscle development by myocyte enhancer factor-2 (MEF2) proteins. Annual Review of Cell and Developmental Biology. 1998; 14:167-96.

101. Morin S, Charron F, Robitaille L, Nemer M. GATAdependent recruitment of MEF2 proteins to target promoters. The EMBO Journal. 2000; 19:2046-55.

102. Taube $\mathrm{R}$, Lin $\mathrm{X}$, Irwin $\mathrm{D}$, Fujinaga $\mathrm{K}$, Peterlin BM. Interaction between $\mathrm{P}-\mathrm{TEFb}$ and the $\mathrm{C}$-terminal domain of RNA polymerase II activates transcriptional elongation from sites upstream or downstream of target genes. Molecular and Cellular Biology. 2002; 22:321-31.

103. Nojima M, Huang Y, Tyagi M, Kao H-Y, Fujinaga K. The positive transcription elongation factor $\mathrm{b}$ is an essential cofactor for the activation of transcription by myocyte enhancer factor 2. Journal of Molecular Biology. 2008; 382:275-87.

104. Cox DM, Du M, Marback M, Yang ECC, Chan J, Siu KWM, McDermott JC. Phosphorylation motifs regulating the stability and function of myocyte enhancer factor $2 \mathrm{~A}$. The Journal of Biological Chemistry. 2003; 278:15297-303.

105. Kato Y, Zhao M, Morikawa A, Sugiyama T, Chakravortty
D, Koide N, Yoshida T, Tapping RI, Yang Y, Yokochi T, Lee JD. Big mitogen-activated kinase regulates multiple members of the MEF2 protein family. The Journal of Biological Chemistry. 2000; 275:18534-40.

106. Du M, Perry RLS, Nowacki NB, Gordon JW, Salma J, Zhao J, Aziz A, Chan J, Siu KWM, McDermott JC. Protein kinase A represses skeletal myogenesis by targeting myocyte enhancer factor 2D. Molecular and Cellular Biology. 2008; 28:2952-70.

107. Grégoire S, Tremblay AM, Xiao L, Yang Q, Ma K, Nie J, Mao Z, Wu Z, Giguère V, Yang X-J. Control of MEF2 transcriptional activity by coordinated phosphorylation and sumoylation. The Journal of Biological Chemistry. 2006; 281:4423-33.

108. Kang J, Gocke CB, Yu H. Phosphorylation-facilitated sumoylation of MEF2C negatively regulates its transcriptional activity. BMC biochemistry. 2006; 7:5.

109. Zhu B, Gulick T. Phosphorylation and alternative premRNA splicing converge to regulate myocyte enhancer factor 2C activity. Molecular and Cellular Biology. 2004; 24:8264-75.

110. Di Giorgio E, Gagliostro E, Clocchiatti A, Brancolini C. The control operated by the cell cycle machinery on MEF2 stability contributes to the downregulation of CDKN1A and entry into S phase. Molecular and Cellular Biology. 2015; 35:1633-47.

111. Zhu B, Ramachandran B, Gulick T. Alternative premRNA splicing governs expression of a conserved acidic transactivation domain in myocyte enhancer factor 2 factors of striated muscle and brain. The Journal of Biological Chemistry. 2005; 280:28749-60.

112. Hakim NHA, Kounishi T, Alam AHMK, Tsukahara T, Suzuki H. Alternative splicing of Mef2c promoted by Fox-1 during neural differentiation in P19 cells. Genes to Cells: Devoted to Molecular \& Cellular Mechanisms. 2010; 15:255-67.

113. Zhang M, Zhu B, Davie J. Alternative Splicing of MEF2C Controls its Activity in Normal Myogenesis and Promotes Tumorigenicity in Rhabdomyosarcoma Cells. The Journal of Biological Chemistry. 2015; 290:310-24.

114. Friedrich FW, Dilanian G, Khattar P, Juhr D, Gueneau L, Charron P, Fressart V, Vilquin J-T, Isnard R, Gouya L, Richard P, Hammoudi N, Komajda M, et al. A novel genetic variant in the transcription factor Islet-1 exerts gain of function on myocyte enhancer factor $2 \mathrm{C}$ promoter activity. European Journal of Heart Failure. 2013; 15:26776.

115. Paciorkowski AR, Traylor RN, Rosenfeld JA, Hoover JM, Harris CJ, Winter S, Lacassie Y, Bialer M, Lamb AN, Schultz RA, Berry-Kravis E, Porter BE, Falk M, et al. MEF2C Haploinsufficiency features consistent hyperkinesis, variable epilepsy, and has a role in dorsal and ventral neuronal developmental pathways. Neurogenetics. 2013; 14:99-111. 
116. Zweier M, Gregor A, Zweier C, Engels H, Sticht H, Wohlleber E, Bijlsma EK, Holder SE, Zenker M, Rossier E, Grasshoff U, Johnson DS, Robertson L, et al. Mutations in MEF2C from the 5q14.3q15 microdeletion syndrome region are a frequent cause of severe mental retardation and diminish MECP2 and CDKL5 expression. Human Mutation. 2010; 31:722-33.

117. Ryan SD, Dolatabadi N, Chan SF, Zhang X, Akhtar MW, Parker J, Soldner F, Sunico CR, Nagar S, Talantova M, Lee B, Lopez K, Nutter A, et al. Isogenic human iPSC Parkinson's model shows nitrosative stress-induced dysfunction in MEF2-PGC1 $\alpha$ transcription. Cell. 2013; 155:1351-64.

118. Wang B, Cai Z, Lu F, Li C, Zhu X, Su L, Gao G, Yang Q. Destabilization of survival factor MEF2D mRNA by neurotoxin in models of Parkinson's disease. Journal of Neurochemistry. 2014; 130:720-8.

119. Morrow EM, Yoo S-Y, Flavell SW, Kim T-K, Lin Y, Hill RS, Mukaddes NM, Balkhy S, Gascon G, Hashmi A, AlSaad S, Ware J, Joseph RM, et al. Identifying autism loci and genes by tracing recent shared ancestry. Science (New York, NY). 2008; 321:218-23.

120. Burton TR, Dibrov A, Kashour T, Amara FM. Antiapoptotic wild-type Alzheimer amyloid precursor protein signaling involves the p38 mitogen-activated protein kinase/ MEF2 pathway. Brain Research Molecular Brain Research. 2002; 108:102-20.

121. Greer PL, Hanayama R, Bloodgood BL, Mardinly AR, Lipton DM, Flavell SW, Kim T-K, Griffith EC, Waldon Z, Maehr R, Ploegh HL, Chowdhury S, Worley PF, et al. The Angelman Syndrome protein Ube3A regulates synapse development by ubiquitinating arc. Cell. 2010; 140:704-16.

122. Wang L, Fan C, Topol SE, Topol EJ, Wang Q. Mutation of MEF2A in an inherited disorder with features of coronary artery disease. Science (New York, NY). 2003; 302:157881.

123. Firth HV, Richards SM, Bevan AP, Clayton S, Corpas M, Rajan D, Van Vooren S, Moreau Y, Pettett RM, Carter NP. DECIPHER: Database of Chromosomal Imbalance and Phenotype in Humans Using Ensembl Resources. American Journal of Human Genetics. 2009; 84:524-33.

124. Homminga I, Pieters R, Langerak AW, de Rooi JJ, Stubbs A, Verstegen M, Vuerhard M, Buijs-Gladdines J, Kooi C, Klous P, van Vlierberghe P, Ferrando AA, Cayuela JM, et al. Integrated transcript and genome analyses reveal NKX2-1 and MEF2C as potential oncogenes in T cell acute lymphoblastic leukemia. Cancer Cell. 2011; 19:484-97.

125. Prima V, Hunger SP. Cooperative transformation by MEF2D/DAZAP1 and DAZAP1/MEF2D fusion proteins generated by the variant $t(1 ; 19)$ in acute lymphoblastic leukemia. Leukemia. 2007; 21:2470-5.

126. Schwieger M, Schüler A, Forster M, Engelmann A, Arnold MA, Delwel R, Valk PJ, Löhler J, Slany RK, Olson EN, Stocking C. Homing and invasiveness of MLL/ENL leukemic cells is regulated by MEF2C. Blood. 2009;
114:2476-88.

127. Du Y, Spence SE, Jenkins NA, Copeland NG. Cooperating cancer-gene identification through oncogenic-retrovirusinduced insertional mutagenesis. Blood. 2005; 106:2498505.

128. Krivtsov AV, Twomey D, Feng Z, Stubbs MC, Wang Y, Faber J, Levine JE, Wang J, Hahn WC, Gilliland DG, Golub TR, Armstrong SA. Transformation from committed progenitor to leukaemia stem cell initiated by MLL-AF9. Nature. 2006; 442:818-22.

129. Bai X, Wu L, Liang T, Liu Z, Li J, Li D, Xie H, Yin S, Yu J, Lin Q, Zheng S. Overexpression of myocyte enhancer factor 2 and histone hyperacetylation in hepatocellular carcinoma. Journal of Cancer Research and Clinical Oncology. 2008; 134:83-91.

130. Ma L, Liu J, Liu L, Duan G, Wang Q, Xu Y, Xia F, Shan J, Shen J, Yang Z, Bie P, Cui Y, Bian X-W, et al. Overexpression of the transcription factor MEF2D in hepatocellular carcinoma sustains malignant character by suppressing G2-M transition genes. Cancer Research. 2014; 74:1452-62.

131. Cerami E, Gao J, Dogrusoz U, Gross BE, Sumer SO, Aksoy BA, Jacobsen A, Byrne CJ, Heuer ML, Larsson E, Antipin Y, Reva B, Goldberg AP, et al. The cBio cancer genomics portal: an open platform for exploring multidimensional cancer genomics data. Cancer Discovery. 2012; 2:401-4.

132. Gao J, Aksoy BA, Dogrusoz U, Dresdner G, Gross B, Sumer SO, Sun Y, Jacobsen A, Sinha R, Larsson E, Cerami E, Sander C, Schultz N. Integrative analysis of complex cancer genomics and clinical profiles using the cBioPortal. Science Signaling. 2013; 6:pl1.

133. Bai XL, Zhang Q, Ye LY, Liang F, Sun X, Chen Y, Hu QD, Fu QH, Su W, Chen Z, Zhuang ZP, Liang TB. Myocyte enhancer factor $2 \mathrm{C}$ regulation of hepatocellular carcinoma via vascular endothelial growth factor and $\mathrm{Wnt} / \beta$-catenin signaling. Oncogene. 2015; 34:4089-97.

134. Akhurst RJ, Derynck R. TGF-beta signaling in cancer-a double-edged sword. Trends in cell biology. 2001; 11:S4451.

135. Tam WL, Weinberg RA. The epigenetics of epithelialmesenchymal plasticity in cancer. Nature medicine. 2013; 19:1438-49.

136. Zhang J-J, Zhu Y, Xie K-L, Peng Y-P, Tao J-Q, Tang J, Li Z, Xu Z-K, Dai C-C, Qian Z-Y, Jiang K-R, Wu J-L, Gao $\mathrm{W}-\mathrm{T}$, et al. Yin Yang-1 suppresses invasion and metastasis of pancreatic ductal adenocarcinoma by downregulating MMP10 in a MUC4/ErbB2/p38/MEF2C-dependent mechanism. Molecular Cancer. 2014; 13:130.

137. Chang S, Young BD, Li S, Qi X, Richardson JA, Olson EN. Histone deacetylase 7 maintains vascular integrity by repressing matrix metalloproteinase 10. Cell. 2006; 126:321-34.

138. Cancer Genome Atlas Research Network, Kandoth C, Schultz N, Cherniack AD, Akbani R, Liu Y, Shen H, 
Robertson AG, Pashtan I, Shen R, Benz CC, Yau C, Laird PW, et al. Integrated genomic characterization of endometrial carcinoma. Nature. 2013; 497:67-73.

139. Cancer Genome Atlas Research Network. Comprehensive molecular characterization of gastric adenocarcinoma. Nature. 2014; 513:202-9.

140. Cancer Genome Atlas Research Network. Comprehensive molecular characterization of urothelial bladder carcinoma. Nature. 2014; 507:315-22.

141. Di Giorgio E, Clocchiatti A, Piccinin S, Sgorbissa A, Viviani G, Peruzzo P, Romeo S, Rossi S, Tos AP Dei, Maestro R, Brancolini C. MEF2 is a converging hub for histone deacetylase 4 and phosphatidylinositol 3-kinase/ Akt-induced transformation. Molecular and Cellular Biology. 2013; 33:4473-91.

142. Zhang M, Truscott J, Davie J. Loss of MEF2D expression inhibits differentiation and contributes to oncogenesis in rhabdomyosarcoma cells. Molecular Cancer. 2013; 12:150.

143. Morin RD, Mendez-Lago M, Mungall AJ, Goya R, Mungall KL, Corbett RD, Johnson NA, Severson TM, Chiu R, Field M, Jackman S, Krzywinski M, Scott DW, et al. Frequent mutation of histone-modifying genes in non-Hodgkin lymphoma. Nature. 2011; 476:298-303.

144. Lohr JG, Stojanov P, Lawrence MS, Auclair D, Chapuy B, Sougnez C, Cruz-Gordillo P, Knoechel B, Asmann YW, Slager SL, Novak AJ, Dogan A, Ansell SM, et al. Discovery and prioritization of somatic mutations in diffuse large B-cell lymphoma (DLBCL) by whole-exome sequencing. Proceedings of the National Academy of Sciences of the United States of America. 2012; 109:3879-84.

145. Pasqualucci L, Trifonov V, Fabbri G, Ma J, Rossi D, Chiarenza A, Wells VA, Grunn A, Messina M, Elliot O, Chan J, Bhagat G, Chadburn A, et al. Analysis of the coding genome of diffuse large B-cell lymphoma. Nature Genetics. $2011 ; 43: 830-7$

146. Zhang J, Grubor V, Love CL, Banerjee A, Richards KL, Mieczkowski PA, Dunphy C, Choi W, Au WY, Srivastava G, Lugar PL, Rizzieri DA, Lagoo AS, et al. Genetic heterogeneity of diffuse large B-cell lymphoma. Proceedings of the National Academy of Sciences of the United States of America. 2013; 110:1398-403.

147. Beà S, Valdés-Mas R, Navarro A, Salaverria I, MartínGarcia D, Jares P, Giné E, Pinyol M, Royo C, Nadeu F, Conde L, Juan M, Clot G, et al. Landscape of somatic mutations and clonal evolution in mantle cell lymphoma. Proceedings of the National Academy of Sciences of the United States of America. 2013; 110:18250-5.

148. Meissner B, Kridel R, Lim RS, Rogic S, Tse K, Scott DW, Moore R, Mungall AJ, Marra MA, Connors JM, Steidl C, Gascoyne RD. The E3 ubiquitin ligase UBR5 is recurrently mutated in mantle cell lymphoma. Blood. 2013; 121:31614.

149. Rai D, Kim S-W, McKeller MR, Dahia PLM, Aguiar RCT. Targeting of SMAD5 links microRNA-155 to the
TGF-beta pathway and lymphomagenesis. Proceedings of the National Academy of Sciences of the United States of America. 2010; 107:3111-6.

150. Jiang D, Aguiar RCT. MicroRNA-155 controls RB phosphorylation in normal and malignant B lymphocytes via the noncanonical TGF- $\beta 1 /$ SMAD5 signaling module. Blood. 2014; 123:86-93.

151. Ott G, Rosenwald A, Campo E. Understanding MYCdriven aggressive B-cell lymphomas: pathogenesis and classification. Blood. 2013; 122:3884-91. 